\title{
On the Philosophical Perspective of Mao Zedong's International Strategic Theory
}

\author{
Han Yin \\ The department of political education, Wenhua College, Wuhan 430074, China. \\ 16819027@qq.com
}

Keywords: Mao Zedong's international strategic theory the perspective of philosophical thinking.

\begin{abstract}
From 1946 to 1970s, the theory of Mao Zedong's international strategy has gone through three stages of development that is the thinking of "the middle zone" - the thinking of two middle zones" -"three world theory. In these ideas, Mao Zedong has profound philosophical principles for the deconstruction of the international community. he is based on Marx's materialist dialectics, four basic perspectives of the struggle thinking, the overall thinking, thinking for the people and the strain thinking, observe and analyse the various phenomena of the international community, it is an important aspect that we should study todayFrom 1946 to the 1970s, Mao Zedong's international strategic theory has gone through three stages of development, that is "the intermediate zone" thought - "two intermediate zones" thought - "three worlds division" theory. In these thoughts, Mao Zedong's deconstruction equation of international community contains profound philosophical principles. Mao Zedong applies Marxist philosophy as an analysis tool, starting from the opposite and unity of contradiction, analyzes the interest relationship between the political entities of the international community, and puts forward "who is our enemy, who is our friend" in the first place of the diplomatic strategy, provides a theoretical model for the systematic analysis of the international political situation. Today, on the way to the great rejuvenation of the chinese nation, we should pay attention to the following four basic points by studying the philosophical ideas contained in Mao Zedong's international strategic theory.
\end{abstract}

\section{The Struggle Thinking Perspective}

Mao Zedong attaches great importance to the struggle of contradiction. Mao Zedong's theory of international strategy fully embodies the world outlook of struggle philosophy, which is a kind of understanding about the world. "whatever the movement, it takes two states: a state of relative stillness and a state of marked change. The motion of both states is caused by the struggle of two contradictory factors within the object."[1] he said. when Mao Zedong led his people to make a revolution, The harder the situation was, the more tenacious his fighting spirit would be. He had been remained convinced: "reactionaries will fail one day, we shall win one day."[2] During the early days of founding new nation, in the case of the devastated China waiting for founding and prospering, Mao Zedong faces the ambition of American imperialism to seek hegemony, he resolutely decided to resist US aggression and aid Korea. It not only fully embodies his fearless spirit of daring to fight, but also is the best practice of the "middle zone" theory. He firmly believed that only by uniting, supporting and participating in the anti-colonization and anti-hegemonism struggle of countries in the "middle zone" can we build a peaceful and stable development environment for New China, and enhance China's international position. In 1960s, the Soviet Union's chauvinist tendencies became increasingly apparent. In 1960s, the Soviet Union's tendency towards chauvinism became increasingly evident, it attempted to force China to meet its strategic needs. At this time, Mao Zedong's consciousness of struggle was aroused again. He developed the theory of "middle zone" into the theory of "two intermediate zones", and opposed both American imperialism and Soviet revisionism. Mao Zedong withstood all kinds of pressure from the Soviet Union, including withdrawing experts, tearing up contracts, interrupting economic and military assistance to China, and wage a resolute struggle against the Soviet Union's chauvinistic acts. At the same time, Mao 
Zedong encouraged and supported the world's anti-hegemony and anti-colonization war of national independence, he hoped that they would persevere until the final victory. Because "the belief in victory is fought out and gained during the struggle."[3] Although Mao Zedong Mao Zedong likes to fight, Mao Zedong is not aggressive. It is a purposeful fight on the basis of adhering to the principle. Mao Zedong's purpose is to safeguard the independence and security of the country, world peace and development. Just as Mao Zedong said in explaining the reasons for resisting US aggression and aiding Korea: "We should not invade any country, we are only opposed to the imperialist aggression against our country." "since the American aggressors have already attacked us, we had to raise the banner of anti-aggression, which is absolutely necessary and completely just." [4]

Mao Zedong stressed the conflict, but also pay great attention to the joint under the struggle. Because he knows that struggle is not the only way to solve conflicts. After the founding of the people's Republic of China, under the guidance of the theory of “middle zone”, the one-sided international strategic policy of was implemented. China firmly stood on the side of the socialist camp headed by the Soviet Union, and opposed to the United States-led imperialist camp, the lines between the enemy and us are clear, but this does not mean that in the face of the United States, only struggle, not cooperation. On the one hand, Mao Zedong resolutely opposed the aggressive policy of the United States, and don't allow it to interfere in China's internal affairs; On the other hand, he did not take the initiative to provoke conflicts and strive for the peaceful settlement of Sino-US disputes, that is, to handle Sino-US relations in accordance with the five principles of peaceful coexistence, and "hope that the United States will also adopt a policy of peaceful coexistence." [5] In the face of the Soviet Union, Mao Zedong is not blindly obedient, In 1960s, when the Soviet Union made unreasonable demands that undermined China's sovereignty, he fought against it uncompromisingly. He put forward the theory of "two intermediate zones". He established an international United front against the "American Emperor" and "the Soviet Union", changed the object of the alliance from the Soviet Union to the vast colonies and semi-colonial countries of Asia, Africa, Latin America, as well as Britain, France and other capitalist countries that have contradictions with the United States and the Soviet Union. At the end of 60s, Sino-Soviet relations are tense and explosive; China and the United States continue to keep confrontational. In the harsh international political environment, Mao Zedong realize that "two hegemony, we must always strive for one hegemony", for this reason, he adjusted the international strategy once again. He put the Soviet Union as the primary enemy, China and the United States are gradually moving from confrontation to union.

At present, Mao Zedong's struggle thinking is an important inspiration for building a harmonious socialist society. The "harmony" in the concept of harmony is not an unprincipled "harmony", but a adherence to the principle. The harmony is on the basis of grasping and dealing well with the relation between the opposite and unity, also resolving contradictions constantly. Only understand "harmony" correctly and be good at achieving unity in struggle, can we resolve the contradiction effectively and found the solution to the problem.

\section{The Global Thinking Perspective}

Engels said: "when we carefully investigate the nature or human history or our own spiritual activities, the first thing that comes before us, It is an inexhaustible picture of all kinds of connections and interactions."[6] We only recognize nature, human society is a unity of contradiction made up of universally connected things, and we can pay attention to all kinds of relations between things and things when we deal with problems. In the theory of Mao Zedong's international strategy, the global view occupies an important and special position. The overall view emphasizes the dialectical relationship between the whole and the part, between the whole and the part, between the present and the long-term.

Mao Zedong thought that "all the problems that are concerned with the nature of every aspect and stage” are all global problems.[7] He said:"the main and the first issue is always good or bad care for the whole situation and every stage."[7] He stressed the need to see the organic links between different things, different parts, different sides, and different stages of development. Because this 
organic connection reflects the unity of opposites and the overall relationship. In the international strategic theory, Mao Zedong focuses on the overall situation of the world, dialectically analyzes all kinds of contradictions, whether or not to deal with them well, that is related to the development of international politics and also related to China's development. For example, in 60s of the 20th century, Mao Zedong thought that there were three major contradictions among the imperialist countries, between the imperialist and national independent countries, and between the western countries and the United States in the international community. These three contradictions are not only opposite but also unified, which constitutes the contradiction of the interests of the international community at that time, and contains a huge contradictory motive force. It affected the evolution and development of the international community. Mao Zedong, on the basis of an overall analysis of the above-mentioned contradictions, stressed that "there are contradictions between imperialist countries, so we can take advantage of them. They are not so United, the Americans and the British are not so United, the Americans and the West Germans are not so United, nor are Adenauer against the British. So all the workers in the world, the patriotic people oppressed by the imperialists, are many allied forces."[8] This reflects that Mao Zedong has always insisted on handling the dialectical relationship between the overall situation and the local situation, between the present and the long term in the midst of the great contradiction pattern. He emphatically told people to find a solution from the organic connection of unity. This also constituted the strength support of Mao Zedong's international strategic theory.

At present, China is building socialism with Chinese characteristics, we must

learn the overall thinking emphasized in Mao Zedong's international strategic thinking. It requires us to focus on the contradictions of objective existence. It must be a dialectical holistic view instead of metaphysics. To observe and deal with problems from the perspective of this kind of whole thinking requires that people must see the universal connection and the movement changes in the course of the development of things. In this way, we can see the long term. With strategic vision and macro-decision-making ability.

\section{The Thinking Perspective for the People}

Applying Marxism to observe and deal with problems is embodied in the field of social history, that is, to adhere to the thorough materialism, the mass viewpoint, the mass line and the mass method.

By grasping the principal contradictions, Mao Zedong divides and disintegrates the hostile forces and makes the international situation develop towards the people of the chinese people and the people of the world. Mao Zedong gives the world a clear picture of what you support and oppose by defining strategic goals, which is not only conducive to the struggle of the Chinese people, but also conducive to win the support and sympathy of the people of the world; Mao Zedong adheres to principle and will never waver on major issues related to territorial sovereignty and the fundamental interests of the people. Mao Zedong has always believed that in opposing hegemonism and safeguarding world peace, we must rely on the chinese people and the people of the world. Therefore, no matter how powerful imperialism, hegemonism and power politics may be, so long as it endangers the fundamental interests of the Chinese people and the people of the world, the Chinese people are firmly opposed to it. This is a great spirit that the people of the world need to represent human fairness and justice. This spirit has also earned China the high respect of the peoples of the world.

Mao Zedong's thinking for the people in the theory of international strategy has important practical significance for us to formulate international strategy and deal with diplomatic problems today. This is based on the thorough materialism of Marxism, and takes the people's actual needs and satisfaction as the highest standard.

\section{The Strain Thinking Perspective}

Materialist dialectics holds that:"Movement is the fundamental way of existence of all matter, It mainly marks the dynamic process of the change of things." [9] Under the guidance of this viewpoint, 
Mao Zedong holds that the international situation is constantly changing and developing, and we cannot observe and deal with the complicated international affairs with isolated, static and one-sided views. In 1950s, while carrying out the "one-sided” international strategic policy, Mao Zedong focused on uniting the "middle zone" countries. This profoundly reflects Mao Zedong's dynamic observation of the international political situation. And based on the dynamic observation, it provides a new theoretical basis for the adjustment of China's international strategy. He held that there was no absolute single international political structure at any time, and that even under the bipolar structure of fierce confrontation between the United States and the Soviet Union, the development of various political forces was not balanced. The power balance is constantly developing and changing. The subsequent disintegration of the two camps in the United States and the Soviet Union confirmed this view. Especially the contradiction between Western Europe, Japan and the United States became increasingly sharp. The 1956 suez canal affair began to expose these contradictions. This makes Mao Zedong more convinced that "the imperialist camp is not monolithic" and that consistency in basic interests does not cover up their conflicting differences.

In 1960s, African national liberation movement reached its climax, the Non - Aligned Movement was booming. A series of developing country organizations represented by "the Group of 77" have been established. The contradictions between China and the Soviet Union have deepened and become more open and expanded. Because of the imbalance of political and economic development, the tendency of Western capitalist countries to be independent from the United States is becoming more and more obvious. Mao Zedong dialectically analyzed the new situation, and considered that the situation of the world is emerging as "great turmoil, great differentiation and great restructuring", the theory of "two middle zones" is formed. In 1970s, with the expansion of Soviet hegemonism, the relaxation of Sino-American relations and the rise of developing countries, Mao Zedong put forward the theory of "three worlds division". To this day, Mao Zedong's observing and dealing with the strain thinking perspective in international affairs is an important methodological principle that we should always adhere to.

\section{References}

[1]. Mao Zedong’s Anthology (Vol.1) [M].Beijing: People’s publishing House, 1991:332.

[2]. Mao Zedong's diplomatic works [M].Beijing: central Literature Publishing House, World knowledge Publishing House 1994:62.

[3]. Mao Zedong's diplomatic works [M].Beijing: central Literature Publishing House, World knowledge Publishing House, 1994:572.

[4]. Mao Zedong’s Anthology (Vol. 5) [M].Beijing: People’s publishing House, 1977:50.

[5]. Mao Zedong's diplomatic works [M].Beijing: central Literature Publishing House, World knowledge Publishing House, 1994:161.

[6]. Marx and Engels’ Anthology (Vol. 3). [M].Beijing: people’s Publishing House, 1995:359.

[7]. Mao Zedong’s Anthology (Vol. 1) [M].Beijing: People’s publishing House, 1991:175.

[8]. Mao Zedong's Anthology (Vol. 5) [M].Beijing: People’s publishing House, 1996:125, 386,190-191.

[9]. Li Xiulin, ang Yu, i Huai Chun. ialectical materialism and Historical materialism principle[M].Beijing:Renmin University Publishing House,1995:155. 